\title{
An Economic Analysis of Migratory Sheep Production System in Tamill Nadu, India
}

A. Singaravadivelan ${ }^{*}$, N. Kumaravelu ${ }^{2}$, P.Vijayakumar $^{3}$, T. Sivakumar ${ }^{4}$

${ }^{1}$ Department of Livestock Production Management, Veterinary College and Research Institute, TANUVAS, Orathanadu-614 625; ${ }^{2}$ Department of Livestock Production Management, Madras Veterinary College, TANUVAS, Chennai-600 007; ${ }^{3}$ Livestock Farm Complex, Veterinary College and Research Institute, TANUVAS, Orathanadu-614 625; ${ }^{4}$ Veterinary College and Research Institute, TANUVAS, Orathanadu-614 625.

\begin{abstract}
A study was conducted to analyse economics of migratory sheep production and socio-economic status of flock owners in southern agro-climatic zone of Tamil Nadu, India. A total of 100 migratory sheep farmers were randomly selected for the study and divided as small $(<175)$, medium (175- 350) and large (> 350) flocks based on the average flock size for comparison. The migratory sheep flock owners were mostly Hindus and belonged to the backward classes, mainly Konars. The flock owners were mostly of old age group, illiterates and they had more than two decades of experience in migratory sheep farming. Majority of the flock owners were small and marginal dry land farmers with a mean land holding of 4 acres. The cost of rearing sheep was accounted through wages (56.06percent), food for shepherds (22.18percent), veterinary charges (15.41percent) and transportation between migratory places (6.35percent). The sources of returns were by sale of surplus lambs (72.41percent), culled adults (5.11percent), penning charges (19.69percent) and sale of manure (2.79percent). The overall average annual net returns per flock and per adult sheep estimated were Rs.4, 43,664 and Rs.2, 264, respectively; while the corresponding values in small, medium and large flocks were Rs.2,55,015 and Rs.2,180; Rs.4,27,812 and Rs.2,097; and Rs.9,94,279 and Rs.2,486 respectively.
\end{abstract}

Keywords | Socio-economic status, Migratory sheep, Economics, Tamil Nadu

Editor | Asghar Ali Kamboh, Sindh Agriculture University, Tandojam, Pakistan.

Received | January 25, 2019; Accepted | March 25, 2019; Published | April 24, 2019

*Correspondence | A Singaravadivelan, Department of Livestock Production Management, Veterinary College and Research Institute, TANUVAS, Orathanadu-614 625; Email: che.velan@gmail.com

Citation | Singaravadivelan A, Kumaravelu N, Vijayakumar P, Sivakumar T (2019). An economic analysis of migratory sheep production system in tamil nadu, india.. J. Anim. Health Prod. 7(2): 58-64.

DOI | http://dx.doi.org/10.17582/journal.jahp/2019/7.2.58.64

ISSN | 2308-2801

Copyright (C) 2019 et al. This is an open access article distributed under the Creative Commons Attribution License, which permits unrestricted use, distribution, and reproduction in any medium, provided the original work is properly cited.

\section{INTRODUCTION}

$\mathrm{S}_{\mathrm{m}}^{\mathrm{h}}$ heep rearing is an important livelihood for small and marginal farmers of India. Sheep are efficient converters of unutilized poor quality grass and crop residues into meat and skin (Ganesan et al., 2015). The sheep are distinct species among the domestic animals in the world since they have an excellent ability to survive over a prolonged period of drought and semi starvation and are less prone to extreme weather conditions. In the event of failure of seasonal rainfall in the rainfed areas, leading to crop failure, sheep gives the farmers a helping hand and uplifts them (Swarnkar and Singh, 2010).
Sheep in India are mostly maintained on natural vegetation on common grazing lands, wastelands and uncultivated lands, stubbles of cultivated crops and top feeds (tree lopping). The scarcity of the fodder at any time is a function of the stocking rate and carrying capacity of the system at that time, the fodder shortage compels the farmers to adopt suitable coping strategies, among which migration is an important one (Bilegjargal et al., 2017). Some sections of the people practice migratory sheep management as a way of life and have acquired caste/community connotations as well, for example, the Raika community of Rajasthan and Gaddi community in Himachal Pradesh. On the other hand, the temporary migration is a coping strategy to farmers to the risk and uncertainty in the production 
system in the form of deficit rainfall and drought conditions which brings disturbance between the demand-supply equilibrium of the fodder (Suresh et al., 2011).

Migratory system of sheep production is traditional and popular in southern agro-climatic zone of Tamil Nadu. The migratory sheep flocks in southern Tamil Nadu were reared by traditional shepherd mainly belonging to Konar/Yadhav community. These migratory flocks are called in Tamil as 'Varathuaadu'. The period of migration included the severe summer months and during these months, shortage of water and feeding resources force the sheep flocks for longer duration and continuous period of migration (Kumaravelu, 2007).

Migratory sheep production systems are important because they are a rich reservoir of adaptive genes. Migratory production systems not only embody sustainable use; they also act as a crucial counterweight to the ever-narrowing genetic base of high-performing animal breeds. Unfortunately, policy makers, conservationists and animal scientists have failed to recognize the importance of these longstanding human-animal-landscape associations for biodiversity conservation and for rural livelihoods (Rollefson, 2007).

Sheep production is an importanttool for socio-economic change to improve income and quality of life of rural community. Thus, the aim of the present study is to collect a baselinecomprehensive details on socio-economic aspects of sheep farmers of Tamil Nadu, India, over which future development programs can be planned.

\section{MATERIALS AND METHODS}

The study was conducted purposively in the districts of Ramanathapuram, Sivagangai and Pudukkottai in southern agro-climatic zone of Tamil Nadu, India where the migratory system of sheep production is practiced as a traditional occupation by large number of sheep farmers. A total of hundred migratory sheep farmers were selected randomly in the study location and divided as small $(<175)$, medium (175-350) and large (> 350) flocks based on the average flock size for comparison. The socio-economic factors like religion, caste, community, age, literacy level, family type, migratory farming experience, ownership status, land holding and type of land were included in the study. The desirable data were collected through structured and pre-tested questionnaire. The questionnaires were filled on the spot by face-to-face interview with the sheep farmers.

To study the economics of rearing sheep, only the variable cost was considered for the analysis, since the fixed cost was heritable in nature from year to year. The variable cost considered were annual wages and imputed cost of food to the hired shepherds, veterinary costs (deworming, vaccination and treatment) and the cost of transport of stock. The migratory sheep flocks were maintained only on grazing and they were allowed to graze free of cost on harvested paddy fields, barren and uncultivable lands, roadsides and forest areas. So expenses on feed, fodder and concentrates were almost nil and hence ignored. The returns realized were sale of surplus lambs, culled adults, penning charges and sale of manure. Possible returns through emergency sale of sick animals and slaughter for consumption by the shepherds and owners were found to be negligible and hence ignored (Devendran et al., 2012). The flock size was more or less constant throughout the year. Based on the cost and returns, economics werecalculated and presented.

\section{Statistical Analysis}

The data collected were scrutinized, collated and analysed by the conventional tabular analysis in the form of mean, standard error and percentage using the methods suggested by Snedecor and Cochran (1994).

\section{RESULTS AND DISCUSSION}

\section{Religion, Caste, Community, Age, Literacy LEVEL ANd Family Type}

The social status of migratory sheep farmers based on religion, caste, community, age, literacy level and family type in the study area are presented in Table 1 . In all the categories of sheep flocks vast majority of sheep farmers were Hindus ( 99.00 percent), followed by Christians (1.00 percent). Majority of migratory sheep farmers were 'Konars' (93.00 percent). A small proportion of the farmers in small farms belonged to Ambalakarar (3.00 percent), Mukulathor and Christian Udayar (each 1.0 percent) and Devendrakulavellalars (2.00 percent). Migratory sheep farmers from backward community, most backward community and scheduled caste and scheduled tribe constituted 96.00, 4.00 and 2.00 percent respectively. Statistical analysis showed no significant relation between caste and community and farm size. The results of the present findings coincide with that of Kandasamy et al. (2006), Tailor et al. (2006), Kumaravelu (2007), Suresh et al. (2008), Devendran et al. (2012), Rajanna et al. (2012) and Raja et al. (2012), who had reported that sheep rearing was a traditional occupation for certain specific communities in different parts of India with majority of the flock owners being Hindus. In general, sheep rearing was a major occupation of socially backward classes.

In all the flocks studied, majority of the migratory sheep farmers belonged to old age group (62 percent), followed by middle age ( 26 percent) and young age (12 percent). Bhatia et al. (2005), Kumaravelu (2007) and Suresh et al. (2008) observed a similar trend with sheep farmers. On 
the contrary, Misra et al. (2006) and Rajanna et al. (2012) reported that majority of the sheep farmers in their study were middle aged. Since the state of Tamil Nadu is under rapid industrialization, the flock owners wanted their children or youngsters of the family to opt for waged jobs in industries. The majority of the flock owners have made their sons and daughters educated in industrial training institutes, polytechnics and other colleges. This makes the educated youth to prefer the lucrative jobs than the traditional sheep rearing. Statistical analysis showed no significant association between age group and farm size. The overall mean age of a migratory sheep farmer is $46.17 \pm$ 1.00 years.

Literacy level plays a key role in adoption of new technologies in sheep rearing. But unfortunately, 60 percent of migratory sheep farmers were not able to read and write. Similar findings were reported by Bhatia et al. (2005), Dev et al. (2006), Tailor et al. (2006), Suresh et al. (2008) and Rajanna et al. (2012) with the migratory sheep farmers in different parts of India. Hence, the level of acceptance of new scientific practices by farmers becomes low.

As far as family type of migratory sheep holders are concerned, nuclear family type dominated in all types of farms. No difference was found between farm size and family type of sheep holders. Kumaravelu (2007) observed a similar trend with the sheep farmers in Tamil Nadu whereas Suresh et al. (2008) reported that joint family structure was predominant among sheep rearers of Rajasthan.

\section{Experience in Migratory Sheep Farming}

Experience in migratory sheep farming of sheep keepers is presented in Table 2. It was observed that 90 percent of the farmers had more than two decades of experience in migratory sheep farming. Maheswaran (1993), Balakrishnan (1994) and Kumaravelu (2007) have reported similar findings.

\section{Ownership Status of Sheep Farmers}

Ownership status of migratory sheep farmers are presented in Table 3. Majority (95 percent) of the sheep farmers had absolute owning status of sheep, followed by fully owned with sheep taken for lease ( 3 percent). Similar findings were recorded by Kandasamy et al. (2006) and Kumaravelu (2007) in Coimbatore and Ramnad white sheep respectively in Tamil Nadu.

The lease or rental sheep rearing method prevalent among migratory sheep farming, is that all the flock and the receipt from annual sale of lambs and culled adults belonged to flock owners. Rental taker take flocks from one or more owners and night fold them in agricultural fields. The rental taker are paid at the rate of Rs.10,000/- per flock of
100 sheep per year by the flock owners as wages for grazing and tending sheep. Rental takers migrate to different places and night folds them in agricultural field, they also get cash for night folding of sheep from the field owners at Rs. 1 to 2 per sheep per night. The penning charges belonged to the rental takers. All the risks involved belonged to rental takers; while of cost vaccination, deworming and treatment were incurred by flock owners.

\section{LANDHOLDING}

Classifications of sheep farmers based on the agricultural landholding and overall mean landholding of sheep farmers in the study area are presented in Table 4. Majority of farmers holding the small flocks were either landless or small farm holders (27.50 percent). Most of the medium-sized flock owners were small farmers (35.56 percent); while majority of large flock owners (33.33 percent) possessed agricultural land size of above 5 acres. Saravanakumar (2003), Rajapandi (2005), Kandasamy et al. (2006) and Dinesh et al. (2006) observed that majority of the sheep farmers were landless. Whereas Thiruvenkadan et al. (2004), Porwal et al. (2006) and Rajanna et al. (2012) found that the sheep framers were mostly small and marginal farmers. The mean land holding of small, medium and large flock owners were $4.31 \pm 0.40,3.50 \pm 0.26$ and $4.38 \pm 0.70$ acres respectively. The overall mean land holding (acres) of sheep farmers was 4.00 in the study area, which was lower than that reported by Thiruvenkadan et al. (2004), Kandasamy et al. (2006), Dinesh et al. (2006), and Devendran et al. (2012).

It was observed that the flock owners owned more area of dry land, where sheep play an important role in sustainable livelihood of people in rainfed dry land agriculture. Apart from that the migratory sheep flock owners are not depending on agriculture, as their main occupation is sheep rearing. The reduction in the size of land holdings is attributed to fragmentation of agricultural lands to the descendants of the farmers, sale of land for want of money, failure of seasonal rain, conversion of agricultural lands into residential and industrial plots, which has lead overall reduction of agricultural operations.

\section{Economics of Migratory Sheep Rearing}

The cost and returns from rearing of sheep under migratory system is presented in Table 5 . The cost in migratory sheep rearing was maximum on wages and food for hired shepherds followed by veterinary care (vaccination, deworming and treatment) and transportation of lamb hut, penning materials, etc. between migrations. The cost on wages (56.06 percent) and food (22.18 percent) for hired shepherds was the major component of the total expenditure in all categories of farms studied. The cost on wages and food for hired shepherds was higher in large flocks and lesser in small flocks because majority of the large flock 
Table 1: Social status of migratory sheep farmers in southern Tamil Nadu based on religion, caste, community, age, literacy level and family type

\begin{tabular}{|c|c|c|c|c|c|}
\hline Social parameters & Small $(n=40)$ & Medium (n=45) & Large $(n=15)$ & Total (100) & F value \\
\hline \multicolumn{6}{|l|}{ Religion } \\
\hline Hindu & $39(97.50)$ & $45(100.00)$ & $15(100.00)$ & $99(99.00)$ & \multirow[t]{4}{*}{$0.0178^{\mathrm{NS}}$} \\
\hline Muslim & 0 & 0 & 0 & 0 & \\
\hline Christian & $1(2.50)$ & 0 & 0 & $1(1.00)$ & \\
\hline Total & $40(100.00)$ & $45(100.00)$ & $15(100.00)$ & $100(100.00)$ & \\
\hline \multicolumn{6}{|l|}{ Caste } \\
\hline Konar & $34(85.00)$ & $44(97.78)$ & $15(100.00)$ & $93(93.00)$ & \multirow[t]{6}{*}{$0.0257^{\mathrm{NS}}$} \\
\hline Ambalakarar & $2(5.00)$ & $1(2.22)$ & - & $3(3.00)$ & \\
\hline Mukulathor & $1(2.50)$ & 0 & 0 & $1(1.00)$ & \\
\hline Christian Udayar & $1(2.50)$ & 0 & 0 & $1(1.00)$ & \\
\hline Devendrakulavellalars & $2(5.00)$ & 0 & 0 & $2(2.00)$ & \\
\hline Total & $40(100.00)$ & $45(100.00)$ & $15(100.00)$ & $100(100.00)$ & \\
\hline \multicolumn{6}{|l|}{ Community } \\
\hline Backward Class & $35(87.50)$ & $44(97.77)$ & $15(100.00)$ & $94(94.00)$ & \multirow[t]{4}{*}{$0.0039^{\mathrm{NS}}$} \\
\hline Most Backward Class & $3(7.50)$ & $1(2.23)$ & 0 & $4(4.00)$ & \\
\hline Scheduled Castes/Scheduled Tribes & $2(5.00)$ & 0 & 0 & $2(2.00)$ & \\
\hline Total & $40(100.00)$ & $45(100.00)$ & $15(100.00)$ & $100(100.00)$ & \\
\hline \multicolumn{6}{|l|}{ Age group } \\
\hline Young & $7(17.50)$ & $3(6.67)$ & $2(13.33)$ & $12(12.00)$ & \multirow[t]{4}{*}{$0.0332^{\mathrm{NS}}$} \\
\hline Middle & $9(22.50)$ & $14(31.11)$ & $3(20.00)$ & $26(26.00)$ & \\
\hline Old & $24(60.00)$ & $28(62.22)$ & $10(66.67)$ & $62(62.00)$ & \\
\hline Total & $40(100)$ & $45(100)$ & $15(100)$ & $100(100)$ & \\
\hline Age (Mean \pm S.E) & $44.50 \pm 1.54$ & $47.44 \pm 1.44$ & $46.80 \pm 3.05$ & $46.17 \pm 1.00$ & $0.9462^{\mathrm{NS}}$ \\
\hline \multicolumn{6}{|l|}{ Literacy level } \\
\hline Literate & $18(45.00)$ & $15(33.33)$ & $7(46.63)$ & $40(40.00)$ & \multirow[t]{3}{*}{$0.0000^{\mathrm{NS}}$} \\
\hline Illiterate & $22(55.00)$ & $30(66.67)$ & $9(53.37)$ & $60(60.00)$ & \\
\hline Total & $40(100.00)$ & $45(100.00)$ & $15(100.00)$ & $100(100.00)$ & \\
\hline \multicolumn{6}{|l|}{ Family type } \\
\hline Joint & $18(45.00)$ & $15(33.33)$ & $6(40.00)$ & $39(39.00)$ & \multirow[t]{3}{*}{$0.0000^{\mathrm{NS}}$} \\
\hline Nuclear & $22(55.00)$ & $30(66.67)$ & $9(60.00)$ & $61(61.00)$ & \\
\hline Total & $40(100.00)$ & $45(100.00)$ & $15(100.00)$ & $100(100.00)$ & \\
\hline
\end{tabular}

Figures in the parentheses indicate the percent to the total; Ns - Not significant

Table 2: Experience in migratory sheep farming in southern Tamil Nadu

$\begin{array}{llllll}\text { Experience } & \begin{array}{l}\text { Small } \\ (\mathbf{n}=\mathbf{4 0})\end{array} & \begin{array}{l}\text { Medium } \\ (\mathbf{n}=\mathbf{4 5})\end{array} & \begin{array}{l}\text { Large } \\ (\mathbf{n = 1 5 )}\end{array} & \begin{array}{l}\text { Overall } \\ (\mathbf{n}=100)\end{array} & \text { F value } \\ 1-10 \text { years } & 3(7.50) & 0(0.00) & 1(6.67) & 4(4.00) & 0.0075^{\mathrm{NS}} \\ 11-20 \text { years } & 4(10.00) & 2(4.44) & 0(0.00) & 6(6.00) & \\ \text { Above 20 years } & 33(82.50) & 43(95.56) & 14(93.33) & 90(90.00) & \\ \text { Total } & 40(100.00) & 45(100.00) & 15(100.00) & 100(100.00) & \end{array}$

Figures in the parentheses indicate the percent to the total; ${ }^{\text {NS }}$ Not significant

owners engaged hired shepherds for grazing their flocks, whereas small farmers involved directly in grazing their flocks. The health coverage charge was higher in small flocks and lesser in large flock category. The overall aver- age annual total cost was Rs. 38,997/- per flock. The total cost per flock was higher in large flocks and lesser in small flocks. 
Table 3: Ownership status of the migratory sheep farmers in southern Tamil Nadu

\begin{tabular}{|llllll|} 
Type of ownership & $\begin{array}{l}\text { Small } \\
(\mathbf{n}=40)\end{array}$ & $\begin{array}{l}\text { Medium } \\
(\mathbf{n = 4 5 )}\end{array}$ & Large (n=15) & Overall & F value \\
\hline Fully owned & $36(90.00)$ & $44(97.78)$ & $15(100.00)$ & $95(95.00)$ & $0.0005^{\text {NS }}$ \\
\hline Taken for lease & $1(2.50)$ & $1(2.22)$ & $0(0.00)$ & $2(2.00)$ & \\
\hline Both & $3(7.50)$ & $0(0.00)$ & $0(0.00)$ & $3(3.00)$ & \\
\hline Total & $40(100.00)$ & $45(100.00)$ & $15(100.00)$ & $100(100.00)$ & \\
\hline
\end{tabular}

Figures in the parentheses indicate the percent to the total; ${ }^{\text {NS }}$ - Not significant

Table 4: Classification of the migratory sheep farmers in southern Tamil Nadu based on agricultural land holding (Acres)

\begin{tabular}{llllll} 
Particulars & Small $(\mathbf{n}=\mathbf{4 0})$ & Medium $(\mathbf{n}=\mathbf{4 5})$ & Large $(\mathbf{n}=\mathbf{1 5})$ & Total $(\mathbf{n = 1 0 0})$ & F value \\
Categories of farmers & & & & & \\
Large farmers & $10(25.00)$ & $6(13.33)$ & $5(33.33)$ & $21(21.00)$ & $0.0032^{\mathrm{NS}}$ \\
Small farmers & $11(27.50)$ & $16(35.56)$ & $4(26.67)$ & $31(31.00)$ & \\
Marginal farmers & $8(20.00)$ & $11(24.44)$ & $4(26.67)$ & $23(23.00)$ & \\
Landless farmers & $11(27.50)$ & $12(26.67)$ & $2(13.33)$ & $25(25.00)$ & \\
Total & $40(100.00)$ & $45(100.00)$ & $15(100.00)$ & $100(100.00)$ & \\
Area of land owned & & & & & \\
Dry land & $2.35 \pm 0.20$ & $2.11 \pm 0.13$ & $2.50 \pm .50$ & $2.28 \pm 0.12$ & $0.6909^{\mathrm{NS}}$ \\
Range & $1-4$ & $1-4$ & $1-5$ & $1-5$ & \\
Wet land & $2.19 \pm 0.22$ & $2.08 \pm .11$ & $2.45 \pm 0.31$ & $2.19 \pm 0.11$ & $0.7270^{\mathrm{NS}}$ \\
Range & \multicolumn{1}{c}{$1-6$} & $1-4$ & $2-5$ & $1-6$ & \\
Garden land & $2.29 \pm 0.36$ & $2.00 \pm 0.00$ & $2.00 \pm 0.00$ & $2.13 \pm 0.15$ & $0.4334^{\mathrm{NS}}$ \\
Range & $1-4$ & $2-2$ & $2-2$ & $1-4$ & \\
Total & $4.31 \pm 0.40$ & $3.50 \pm 0.26$ & $4.38 \pm 0.70$ & $4.00 \pm 0.23$ & $1.4632^{\mathrm{NS}}$ \\
Range & $1-6$ & $1-4$ & $1-5$ & $1-6$ &
\end{tabular}

Figures in the parentheses indicate the percent to the total; Ns- Not significant

Table 5: Cost and returns from migratory sheep farming in southern Tamil Nadu*

\begin{tabular}{|c|c|c|c|c|}
\hline Particulars & Small & Medium & Large & Overall \\
\hline $\begin{array}{l}\text { Average number of adult sheep } \\
\text { per flock }\end{array}$ & $117.21+5.46$ & $204.00+6.82$ & $400.17+32.30$ & $196.82+11.24$ \\
\hline Number of flocks & 40 & 45 & 15 & 100 \\
\hline \multicolumn{5}{|l|}{ Cost (Rs.) } \\
\hline Wages & $184000(38.50)$ & $963000(56.05)$ & $1039000(60.99)$ & $2186000(56.06)$ \\
\hline Food to shepherds & $76650(16.04)$ & $372300(21.67)$ & $416100(24.43)$ & $865050(22.18)$ \\
\hline Deworming & $98946(20.70)$ & $190386(11.08)$ & $123552(7.25)$ & $412884(10.59)$ \\
\hline Vaccination & $36830(7.70)$ & $70866(4.12)$ & $45989(2.70)$ & $153685(3.94)$ \\
\hline Treatment & $8246(1.73)$ & $15866(0.92)$ & $10296(0.60)$ & $34407(0.88)$ \\
\hline $\begin{array}{l}\text { Transport of lamb hut, penning } \\
\text { materials, etc. }\end{array}$ & $73293(15.33)$ & $105770(6.16)$ & $68640(4.03)$ & $247703(6.35)$ \\
\hline $\begin{array}{l}\text { Total Cost incurred in all the } \\
\text { flocks }\end{array}$ & $477965(100.00)$ & $1718187.4(100.00)$ & $1703577(100.00)$ & $3899729(100.00)$ \\
\hline Total cost per flock & 11949 & 38182 & 113572 & 38997 \\
\hline \multicolumn{5}{|l|}{ Returns (Rs.) } \\
\hline Sale of surplus lambs & $7270400(68.08)$ & $14958100(71.33)$ & $12722800(76.56)$ & $34951300(72.41)$ \\
\hline Sale of culled adults & $937800(8.78)$ & $815200(3.89)$ & $715800(4.31)$ & $2468800(5.11)$ \\
\hline Penning charges & $2148810(20.12)$ & 4577675 (21.83) & $2777625(16.71)$ & $9504110(19.69)$ \\
\hline
\end{tabular}

June 2019 | Volume 7 | Issue 2 | Page 62 


\begin{tabular}{lllll}
\hline Sale of manure & $321575(3.02)$ & $618755(2.95)$ & $401544(2.42)$ & $1341873(2.79)$ \\
$\begin{array}{l}\text { Total returns incurred in all the } \\
\text { flocks }\end{array}$ & $10678585(100.00)$ & $20969730(100.00)$ & $16617769(100.00)$ & $48266083(100.00)$ \\
$\begin{array}{l}\text { Net returnsincurred in all the } \\
\text { flocks }\end{array}$ & 10200620 & 19251542 & 14914192 & 44366354 \\
$\begin{array}{l}\text { Net returns per year per flock } \\
\text { Net returns per year per sheep }\end{array}$ & 255015 & 427812 & 994279 & 443664 \\
\hline
\end{tabular}

Figures in the parentheses indicate the percent to the total

*Exchange rate: 1 USD $=71.09$ INR

The income from migratory sheep farming was obtained mainly through sale of surplus lambs, culled adults, penning charges collected and sale of manure. In the study area, majority of the sheep flock owners penning their sheep in harvested rainfed, irrigated agricultural fields and coconut gardens during night. The sheep farmers charged at the rate of Rs.1.00/sheep/night from the owners of the agricultural fields in lieu of fertilization of the land by penning the sheep flocks. The penning charges are varying from place to place. Daily the penning site was changed to an adjacent site for uniform enrichment of soil. This was one of the important income generation activities forming a major component in migratory sheep farming. The penning and night folding of sheep apart from yielding good returns to the sheep farmers also ensured that the amount was realized regularly for meeting their day-today expenses.

The ram and ewe lambs at age group of one to 3 months were sold for growing and fattening at the rate of Rs. 3000 to 4000 per pair. Stocks at the age group of 6 to 9 months were in demand for meat purpose at the rate of RS.7000 to 8000 per pair. The flock owners prefer to sell ram lambs and ewe lams in pair. Culled rams and ewes were sold at about six year of age for Rs. 10,000-12,000 and Rs. 50006000 per sheep, respectively. The sale of lambs contributed to major share (72.14 percent) of the gross returns, followed by revenue from penning and night folding of sheep (19.69 percent). The present findings are in agreement with Devendran et al. (2012) in migratory Coimbatore sheep flocks and Suresh et al. (2011), Swarnkar and Singh (2010) in Rajasthan. The other sources of income were by sale of culled adults (5.11 percent) and sale of manure (2.79 percent). Almost similar trend was observed irrespective of the flock size.

The overall average annual net returns per flock and per adult sheep estimated were Rs. 4,43,664/- and Rs. 2,264/respectively, which is higher than the findings of Thiruvenkadan et al. (2004) and Singh (2012) in non-migratory sheep flocks, Rajapandi (2005) and Devendran et al. (2012) in migratory Coimbatore sheep flocks and Prabhuet al. (2009) in non-migratory Ramnad White sheep flocks in Tamil Nadu. The corresponding values in small, medium and large flocks were Rs. 2,55,015/- and Rs. 2,180/-; Rs. 4,27,812/- and Rs. 2,097/- ; and Rs. 9,94,279/- and Rs. 2,486/- respectively.

\section{CONCLUSION}

The results of current study demonstrated that majority of the sheep flock owners in southern agro-climatic zone of Tamil Nadu were Hindu 'Konars' (93.00 percent), illiterates (60 percent) and belonged to old age group (62 percent). Nuclear family type was predominant among the flock owners. The flock owners had more than two decades of experience in migratory sheep farming. Majority of the flock owners were small and marginal dry land farmers with a mean land holding of 4 acres. The overall average annual net returns per flock and per adult sheep estimated were Rs.4, 43,664 and Rs.2,264, respectively; whilethe corresponding values in small, medium and large flocks were Rs.2,55,015 and Rs.2,180; Rs.4,27,812 and Rs.2,097; and Rs.9,94,279 and Rs.2,486 respectively.

\section{ACKNOWLEDGEMENTS}

The authors are thankful to the Director, Centre for Animal Production Studies, Tamil Nadu Veterinary and Animal Sciences University, Chennai for providing the facilities to carry out this work.

\section{CONFLICT OF INTEREST}

There is no conflict of interest.

\section{AUTHORS CONTRIBUTION}

A. Singaravadivelan: Main author, N. Kumaravelu: Major advisor, T. Sivakumar: Advisor and P. Vijayakumar: Helped in making manuscript.

\section{REFERENCES}

- Balakrishnan S (1994). A study on goat farming practices in Ramnad district. M.V.Sc. Thesis submitted to Tamil Nadu 
Veterinary and Animal Sciences University, Chennai- 600 051.

- Bhatia J, Pandeyand UK, Suhaga KS (2005). Economic analysis of sheep and goat rearing in rainfed region of Haryana. Indian J. Anim. Sci. 75 (12): 1423-1432.

-Bilegjargal B, Lu Q, Ahmad I, Saeed M (2017). Effect of hypothermia and droughts on livestock mortality in southern and eastern Mongolia. J. Anim. Health. Prod. 5(4): 149-158.

- Dev I, Singh V, Misra B (2006). Socio-economic profile of migratory graziers and Participatory appraisal of forage production and Utilization of an alpine pasture in northwest Himalaya. ENVIS Bulletin, Himalayan Ecol. 11 (2): 52-62.

-Devendran P, Kandasamy N, Panneerselvam S, Selvam S (2012). Economic analysis Coimbatore sheep rearing. Indian J. Small Rumin. 18 (2): 239-243.

-Dinesh K, Singh G, Jain A (2006). Characterization and evaluation of Muzaffarnagari sheep. Indian J. Small Rumin. 12 (1): 48-55.

- Ganesan R, Dhanavanthan P, Balasubramanyam D, Kumarasamy P, Kiruthika (2015). Growth modeling and factors affecting growth traits in Madras red Sheep. Indian J. Anim. Res. 49 (1): 20-25. https://doi.org/10.5958/09760555.2015.00004.7

-Kandasamy N, Paneerselvam S, Devendran P, Thiruvenkadan, AK (2006). Final report on survey evaluation and characterization of Coimbatore sheep breed. Department of Animal Genetics and Breeding, VC\&RI, Namakkal.

-Kumaravelu N (2007). Analysis of sheep production system in southern and northeastern zone of Tamil Nadu. Ph.D., Thesis submitted to Tamil Nadu Veterinary and Animal Sciences University, Chennai-600 051.

- Maheswaran A (1993). Adoption behavior of sheep farmers in Salem district. M.V.Sc., Thesis submitted to Tamil Nadu Veterinary and Animal Sciences University, Chennai- 600 051.

- Misra PK, Subramanyan KV, Vijay Shankar Babu, Reddy TY, Shivarudrappa B, Ramakrishna YS (2006). Improving the livelihood of landless and marginal farmers through sheep rearing in rainfed agro-ecosystems of India. Liv. Res. Rural Dev.18 (5): 56-65.

- Porwal K, Karim SA, Sisodia SL, Singh VK (2006). Socioeconomic survey of sheep farmers in western Rajasthan. Indian J. Small Rumin. 12 (1): 74-81.

- Prabhu M, Selvakumar KN, Serma Saravana Pandian A,
Meganathan N (2009). Economic analysis of sheep farming in Tamil Nadu. Indian J. Small Rumin.15(2): 224-230.

- Raja KN, Jain A, Singh G, Kumar L, Yadav HK, Arora R (2012). Ramnad White sheep-Phenotypic and genetic characterization. Indian J. Anim. Sci. 82 (9): 1082-1086.

- Rajanna N, Mahendar M, Thammpi Raju D, Raghunandan T, Nagalashmi D, Sreenivasa Rao D (2012). Socio-economic status and flock management practices of sheep farmers in Telangana region of Andhra Pradesh. Vet. Res. 5(2): 37-40.

- Rajapandi S (2005). Distribution and management practices of Coimbatore sheep. M.V.Sc., Thesis submitted to Tamil Nadu Veterinary and Animal Sciences University, Chennai-600 051.

-Rollefson IK (2007). Keepers of genes. LIFE network, Sadri, Rajasthan, India.

- Saravanakumar AK (2003). A study on the migratory pattern of Nellore sheep and their performance. M.V.Sc., Thesis submitted to Acharya N.G. Ranga Agricultural University, Hyderabad, Andhra Pradesh.

-Singh BBP (2012). Economic losses due to peste-des-petits ruminants in small ruminants M.V.Sc Thesis submitted to Tamil Nadu Veterinary and Animal Sciences University, Chennai-600 051.

-Suresh A, Gupta DC, Mann JS (2011). Trends, Determinants and Constraints of Temporary Sheep Migration in Rajasthan- An Economic Analysis. Agri. Economics Res. Rev. 24: 255-265.

-Suresh A, Gupta DC, Mann JS (2008). Farmers management practices and economics of sheep rearing on eastern semiarid region of Rajasthan. Indian J. Small Rumin. 14 (2): 236242.

-Snedecor GW and Cochran, WG (1994). Statistical Methods. 8thedn. Oxford and IBH Publishing Company, Kolkata, India.

- Swarnkar CP, Singh D (2010). Questionnaire survey on sheep husbandry and worm management practices adopted by farmers in Rajasthan. Indian J. Small Rumin. 16(2): 199209.

-Tailor SP, Nagda RK, Gupta L (2006). Characterization and evaluation of Sonadi sheep in its native tract. Indian J. Small Rumin. 12, 206-211.

-Thiruvenkadan AK, Karunanithi K, Purushothaman MR (2004). Socio-economic status of the Mecheri sheep farmers and economics rearing under farmer's management. Indian J. Small Rumin. 10 (2): 117-122. 